\title{
Genetic parameters of growth, body, and egg traits in Japanese quails (Cotournix cotournix japonica) reared in southern guinea savannah of Nigeria
}

\author{
O M Momoh, , D Gambo and N I Dim \\ Department of Animal Breeding and Physiology, College of Animal Science, University of Agriculture, Makurdi, \\ Benue State. \\ ${ }^{*}$ Correspondence author: mykemomoh@gmail.com; +234-7036705073
}

Original submitted in on $6^{\text {th }}$ May 2014. Published online at www.m.elewa.org on 31st July 2014. http://dx.doi.org/10.4314/jab.v79i1.8

\begin{abstract}
Objective: This study on Japanese quails was undertaken to estimate heritability values for growth, body and egg traits as well as genetic and phenotypic relationships between these traits in Japanese quails reared in the Southern Guinea Savannah Zone of Nigeria.

Methodology and Results: One hundred and sixty nine (169) pedigree-hatched day-old Japanese quail chicks from 10 sires were used for this study. The data obtained were subjected to variance and correlation analyses as appropriate. Results showed that heritability estimates of body weight at various ages ranged from $0.10 \pm 0.02$ to $0.82 \pm 0.14$ while those of body weight gain were mostly moderate $(0.19 \pm 0.05-0.42 \pm 0.02)$. Linear body parameters had moderate to high $(0.23 \pm 0.13-0.49 \pm 0.16)$ heritability estimates except body length which was $0.08 \pm 0.15$ heritable. Age at first egg (AFE), Body weight at first egg (BWFE) and weight of first egg (WFE) had heritability estimates of $0.48 \pm 0.17,0.56 \pm 0.21$ and $0.38 \pm 0.18$, respectively. Phenotypic correlations between body weights at various ages and egg traits were mostly positive and significant $(p<0.01)$ while that of linear body traits were all positive and mostly significant $(p<0.01)$. Genetic relationships between body weights at various ages were all high and positive. AFE correlated negatively with BWFE while WFE had positive correlation with AFE and BWF.

Conclusion and application of findings: The moderate to high heritability estimates obtained for body weight at ages 1-3 weeks indicates that response to selection for body weight at these ages could be rapid while the low heritability estimates of body weight at week 5 and 6 imply that response to selection for body weight at the 5 th and 6 th week could be slow. It is recommended that selection for body weight or growth rate in Japanese quails should be carried out at early stages of growth, preferably 2-3 weeks of age.
\end{abstract}

Key words: Heritability, Genetic correlation, phenotypic correlation, selection, Body measurements

\section{INTRODUCTION}

Japanese quail is the smallest avian species farmed for meat and egg production (Panda and Singh, 1990) and it has assumed worldwide importance not only as a laboratory animal (Baumgartner, 1993) but also as supplier of meat and eggs, especially for the rural poor and the landless. Distinct characteristics of the Japanese quail which, include rapid growth, thus enabling the quail to be marketed for consumption at 5-6 weeks of age, early sexual maturity, which results in short generation interval, disease 

quails reared in southern guinea savannah, Nigeria

resistance, less capital requirement, high rate of lay and much lower feed and space requirement than domestic fowl (Adeogun and Adeoye, 2004) have further given the birds advantage and attention from researchers in recent times. Moreover, the meat which is highly nutritive delicious, with low caloric value and high dry matter ((Muthukumar and Dev Roy, 2005)) is preferred by all. It is rich in protein, vitamins, essential amino acids, saturated fatty acids, unsaturated fatty acids and phospholipids (Muthukumar and Dev Roy, 2005). In view of the importance of this small stock, it is necessary to initiate improvement programs that can genetically improve the birds for efficient and effective productivity. In order to establish a breeding program, it is essential to estimate genetic parameters for improving the most important economic traits. The magnitude of the genetic parameter, for example heritability, could indicate the amount of improvement that can be achieved by selection. Several workers have reported some estimates of genetic parameters for various traits of

\section{MATERIALS AND METHODS}

The experiment was carried out at Mundi's Farm behind the Livestock Teaching and Research Farm of the Faculty of Agriculture, Nasarawa State University, Lafia, Nasarawa State. Nasarawa State falls within the Southern Guinea Savannah zone of Nigeria. The state lies between latitude $7^{\circ}$ and $9^{\circ}$ North and Longitude $7^{\circ}$ and $10^{\circ}$ East. It has a climate typical of the tropical zone because of its location. It has a temperature ranging from $25^{\circ} \mathrm{C}$ in October to $36^{\circ} \mathrm{C}$ in March while rainfall varies from $13.73 \mathrm{~cm}$ in some places to $14 \mathrm{~cm}$ in others (Nasarawa State Ministry of Information, 2006).

Experimental Birds and Their Management: The base population of the Japanese quails used in this experiment is part of an original random bred population purchased from the Poultry unit of the National Veterinary Research Institute (NVRI), Vom, Plateau State. Thirty (30) females and ten (10) males of this base population were used in the study. They were housed in the same pen for two weeks for the purpose of acclimatization. At the 6th week of age, they were randomized into 10 breeding cages in the rearing house. A mating ratio of 1:3 (i.e. 1 cock to 3 hens) was used. The birds were fed formulated diet containing $18 \%$ crude protein and $2700 \mathrm{Kcal} / \mathrm{Kg}$ metabolizable energy as recommended by Dafwang the Japanese quail. Kawahara and Saito (1976) reported genetic parameter estimates of different organs and body weight in Japanese quail. Toelle et al. (1991) estimated genetic and phenotypic relationship between body weight, carcass and some organ parameters. In Nigeria, most studies on quails have been conducted in the area of production, nutrition, management and health (NVRI, 1996; Bawa, 2006; Chindo and Olowaniyan, 2006; Dafwang, 2006; Tuleun et al., 2008). However, apart from the work of Adeogun and Adeoye (2004); Akpa et al. (2008) and Daikwo (2011), there is little evidence of genetic work done on Japanese quails in Nigeria. Moreover, genetic parameters, especially, heritability estimates are population characteristics and environment specific. They change over time and need to be recomputed from time to time. The objective of this study, therefore, was to estimate heritability values for growth, body and egg traits as well as genetic and phenotypic relationships between these traits in Japanese quails reared in the Southern Guinea Savannah Zone of Nigeria.

(2006). Feed and water were provided ad libitum. Eggs for hatching were collected only when the birds were at least 9 weeks of age. This is because higher rates of fertility and hatchability of Japanese quail eggs are achieved between 9 - 19 weeks of age (Daikwo, 2011). The eggs were held in egg crates under room temperature with good ventilation. At the end of 6 days of egg collection, the eggs were set for pedigree hatching in an electric incubator. On hatching, chicks were weighed and given individual and sire identities using permanent marker of various colours. The chicks were then taken to a brooding room immediately for brooding. The quail chicks were kept at a temperature of $35^{\circ} \mathrm{C}$ with adequate drinker and feeder spaces provided. Light was provided for 24 hours during brooding to avoid pilling and death. The temperature was reduced gradually at the rate of $3.5^{\circ} \mathrm{C}$ on weekly basis as brooding progressed. The chick phase lasted for 3 weeks (21 days). During this phase, the birds were fed formulated chick mash, which contained $24 \%$ crude protein (CP) and $2800 \mathrm{Kcal} / \mathrm{kg}$ metabolizable energy. After the chick phase was the growers phase, which lasted for another three weeks, during which time the birds were fed growers mash containing $21 \% \mathrm{CP}$ and $3000 \mathrm{kcal} / \mathrm{kg}$ metabolizable 

quails reared in southern guinea savannah, Nigeria

energy. Layers mash, which contained $20 \% \mathrm{CP}$ and $2,600 \mathrm{Kcal} / \mathrm{kg}$ metabolizable energy, was given to the birds at point of lay ( 6 weeks of age). The birds were then allowed to lay and records of egg production were taken for the first three months (part-period egg production) to determine egg traits. Though quail is known to be resistant to most diseases of poultry (Modern Farming Methods, 2014). Antistress vitamins (vitalyte®), antibiotics and coccidiostats were administered through water at various times to prevent possible disease outbreak. In addition, good hygiene, cleanliness and biosecurity measures were ensured throughout the experimental period.

\section{Measurement of Traits}

Body Weight: Live body weights were measured at hatching using sensitive electronic scale and then at weekly intervals after wards until 6 weeks of age.

Body Weight Gain: Average daily gains (ADG) for the periods, $0-1,1-2,2-3,3-4,4-5$ and 5-6 weeks were estimated using the Formula:

$$
\frac{W 2-W 1}{N}
$$

Where:

W2= weight at the current week

$\mathrm{W} 1=$ weight at the previous week

$\mathrm{N}$ is the number of days from the previous weight to the present weight.

Linear Body Measurement: The linear body measurements such as body length, shank length, wing lengths and breast girth were measured at weekly intervals until 6 weeks of age using measuring tape.

Age at First Egg (AFE): Quails lay their first egg at this age. In this experiment, this was the age of the birds when the first egg was laid in the flock.

Body Weight at First Egg (BWFE): This was the average weight of the hens when the first egg was laid.

Weight of First Egg (WFE): The weight of first egg for each quail hen was taken using sensitive electronic scale. The average weight of all the first eggs was taken as the weight of first egg.

Egg Number: The total numbers of eggs laid by each hen was recorded monthly for a period of 3 months (part period egg production).

Egg Weight: The weights of the first 3 eggs of each hen were taken in grams at week 1 , week 4 , week 8 and week 12 of lay to determine average egg weight.

Experimental Design: The design of the experiment was a nested or hierarchical design. In other word, random samples of dams were nested within random sample of sires.

Data Analysis: Heritability of, genetic and phenotypic correlations among growth, body, and egg traits were estimated using the mixed model least-squares and maximum likelihood computer programme of Harvey (1990). The reduced sire model (Becker, 1992) was used to fit the data.

$Y_{i j}=\mu+S_{i}+e_{i j}$

$Y_{i j}=$ Observation on the $j^{\text {th }}$ progeny of the $i^{\text {th }}$ sire.

$\mu=$ Overall mean (constant)

$S_{i}=$ Random effect of the $i^{\text {th }}$ sire $(i=1,2, \ldots . .10)$

$\mathrm{e}_{\mathrm{ij}}=$ Random residual error

The Harvey programme computes estimates of genetic and phenotypic correlations as well as heritability estimates from sire variance components. The following formulae are used by the Harvey programme:

$$
\begin{aligned}
& \text { Heritability: } \\
& h^{2}=\quad \frac{4 \sigma_{s}^{2}}{\sigma_{s}^{2}+\sigma^{2}{ }_{e}}
\end{aligned}
$$

Genetic correlation:

$$
r_{G}=\frac{\operatorname{covs}}{\sqrt{\sigma_{s(x)}^{2} \sqrt{\sigma_{s(y)}^{2}}}}
$$

\section{Phenotypic correlation:}

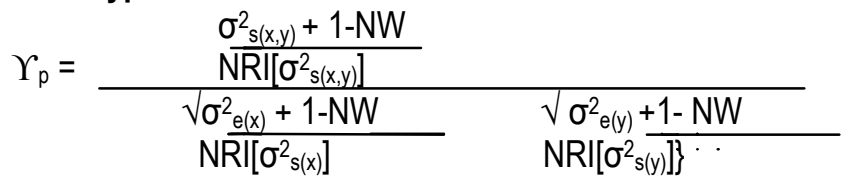

Where:

$h^{2}=$ heritability estimate from paternal half-sib analysis.

$\Upsilon_{G}=$ estimate of genetic correlation.

$\Upsilon_{P}=$ estimate of phenotypic correlation.

$\sigma_{s}{ }^{2}=$ cross classified "family" variance component estimate, otherwise known as sire variance component. $\sigma_{\mathrm{e}}{ }^{2}=$ within family variance component, otherwise known as error variance component.

$\mathrm{NW}=$ decimal percentage of additively genetic variance in $\sigma^{2}$.

$\mathrm{NRI}=$ decimal percentage of additively genetic variance in $\sigma^{2}$ s. 


\section{RESULTS}

The least squares means \pm SEM and heritability estimates of body weight at various ages and body weight gain in Japanese quail are presented in Table 1. Heritability values for body weight decreased with the age of the bird. Estimates of heritability of body weight was high at hatch, week 1 and week 2, moderate at weeks 3 and 4 and low at the 5th and 6th week, respectively. The heritability estimates of body weight gain on the other hand did not follow a particular trend with respect to age. Estimates generally ranged from low $(0.19 \pm 0.05)$ to high $(0.42 \pm 0.02)$.

TABLE 1: Least Squares Means $\pm S E M(g)$ and heritability $\left(h^{2} \pm S . E\right)$ estimates of growth traits in Japanese quails

\begin{tabular}{cccc}
\hline Parameters & No. of Observation & Mean \pm SEM & $\mathbf{h}^{2} \pm$ S.E \\
\hline Body weight & & & \\
Hatch weight & 169 & $5.74 \pm 1.10$ & $0.82 \pm 0.14$ \\
Week 1 & 138 & $10.88 \pm 1.10$ & $0.77 \pm 0.26$ \\
Week 2 & 134 & $23.70 \pm 1.18$ & $0.45 \pm 0.03$ \\
Week 3 & 134 & $34.73 \pm 1.18$ & $0.33 \pm 0.15$ \\
Week 4 & 134 & $54.54 \pm 1.19$ & $0.25 \pm 0.14$ \\
Week 5 & 132 & $76.08 \pm 1.20$ & $0.16 \pm 0.04$ \\
Week 6 & 132 & $89.81 \pm 1.20$ & $0.10 \pm 0.02$ \\
Body weight gain & & & \\
0-1 Week & 138 & $0.74 \pm 0.05$ & $0.31 \pm 0.07$ \\
1-2 Week & 134 & $1.83 \pm 0.05$ & $0.19 \pm 0.05$ \\
2-3 Week & 134 & $1.58 \pm 0.09$ & $0.42 \pm 0.02$ \\
3-4 Week & 134 & $2.87 \pm 0.13$ & $0.30 \pm 0.03$ \\
4-5 Week & 132 & $3.02 \pm 0.11$ & $0.26 \pm 0.08$ \\
5-6 Week & 132 & $2.14 \pm 0.18$ & $0.29 \pm 0.06$ \\
\hline
\end{tabular}

SEM $=$ Standard error of mean

Least Squares Means $\pm S E M$ and heritability $\left(h^{2} \pm S . E\right)$ estimates of 6-month body measurements and some egg traits in Japanese quail are presented in Table 2. Heritability estimates ranged from $0.08 \pm 0.15$ for body length to $0.49 \pm 0.16$ for breast girth. Values for egg traits ranged from $0.34 \pm 0.18$ for egg number to $0.59 \pm 0.23$ for egg weight.

TABLE 2: Least Squares Means $\pm S E M$ and heritability ( $h^{2} \pm S$.E) estimates of 6-month body measurements and some egg traits in Japanese quail

\begin{tabular}{|c|c|c|c|}
\hline Parameters & No. of Observation & Means \pm SEM & $\mathrm{h}^{2} \pm S . E$ \\
\hline \multicolumn{4}{|l|}{ Body measurement } \\
\hline Shank length $(\mathrm{cm})$ & 132 & $3.93 \pm 0.15$ & $0.40 \pm 0.19$ \\
\hline Breast girth $(\mathrm{cm})$ & 132 & $6.51 \pm 0.07$ & $0.49 \pm 0.16$ \\
\hline Wing length $(\mathrm{cm})$ & 132 & $15.00 \pm 0.17$ & $0.23 \pm 0.13$ \\
\hline Body length $(\mathrm{cm})$ & 132 & $17.99 \pm 0.16$ & $0.08 \pm 0.15$ \\
\hline \multicolumn{4}{|l|}{ Egg traits } \\
\hline Age at first egg (days) & 132 & $54.49 \pm 0.20$ & $0.48 \pm 0.17$ \\
\hline Weight of first egg (g) & 132 & $138.91 \pm 0.64$ & $0.56 \pm 0.21$ \\
\hline Body weight at first egg (g) & 132 & $7.83 \pm 0.08$ & $0.38 \pm 0.18$ \\
\hline Egg weight (g) & 300 & $8.43 \pm 0.06$ & $0.59 \pm 0.23$ \\
\hline Egg number & 42 & $23.19 \pm 0.11$ & $0.34 \pm 0.18$ \\
\hline
\end{tabular}

SEM $=$ Standard error of mean 

quails reared in southern guinea savannah, Nigeria

TABLE 3: Genetic (upper diagonal) and Phenotypic (below diagonal) correlations between body weights at different ages in Japanese quails.

\begin{tabular}{cccccccc}
\hline & Week 0 & Week 1 & Week 2 & Week 3 & Week 4 & Week 5 & Week 6 \\
\hline Week 0 & & 0.66 & 0.51 & 0.80 & 0.70 & 0.71 & 0.31 \\
Week 1 & -0.077 & & 0.81 & 0.71 & 0.68 & 0.73 & 0.55 \\
Week 2 & 0.019 & 0.198 & & 0.73 & 0.85 & 1.01 & 0.64 \\
Week 3 & -0.021 & 0.223 & 0.195 & & 0.82 & 0.89 & 0.57 \\
Week 4 & 0.154 & 0.074 & $0.241^{*}$ & $0.242^{*}$ & & 1.03 & 0.99 \\
Week 5 & 0.206 & 0.214 & $0.273^{*}$ & $0.355^{\star *}$ & $0.388^{\star *}$ & & 0.94 \\
Week 6 & 0.018 & 0.204 & 0.191 & -0.010 & $0.362^{\star *}$ & $0.237^{*}$ & \\
\hline
\end{tabular}

${ }^{*}=\mathrm{P}<0.05,{ }^{* *}=\mathrm{P}<0.01$

Genetic and Phenotypic correlations between body weights at different ages are shown in Table 3. Generally, genetic and phenotypic correlations between body weights at various ages were positive except for phenotypic relationship between body weight at hatch and week 1 and hatch and week 3, which showed negative correlations. Phenotypic correlations between body weight at hatch and week 1, respectively, were weak and not significant with body weights at higher ages. However, at weeks 2, 3 and 4, body weights showed significant phenotypic associations with body weights at weeks 5 and 6 . Genetic correlation between body weight at hatch, weeks 1,2 and 3 were all very high and positive.

TABLE 4: Phenotypic Correlation between linear body parameters of Japanese quail at week 1 and week 6

\begin{tabular}{lllll}
\hline & Body Weight & Body Length & Wing Length & Breast Girth \\
\hline Week 1 & & & & \\
Body length & $0.279^{* *}$ & & & \\
Wing length & 0.174 & $0.610^{* *}$ & & \\
Breast girth & 0.123 & $0.566^{* *}$ & $0.761^{* *}$ & $0.344^{* *}$ \\
Shank length & 0.195 & $0.505^{* *}$ & $0.478^{* *}$ & \\
Week 6 & & & & \\
Body length & $0.386^{* *}$ & & & \\
Wing length & $0.284^{* *}$ & $0.634^{* *}$ & & \\
Breast girth & $0.454^{* *}$ & $0.676^{* *}$ & $0.453^{* *}$ & 0.151 \\
Shank length & 0.083 & 0.091 & 0.116 & \\
\hline
\end{tabular}

${ }^{* *}=\mathrm{P}<0.01, E W T=$ egg weight, $E W=$ egg width, EL=egg length, $S T=$ =shell thickness, $E S I=e g g$ shape index, $Y W=y o l k$ width, $\mathrm{YH}=$ yolk height, $\mathrm{Yl}=$ yolk index, $\mathrm{AW}=$ albumen width, $\mathrm{AH}=$ =albumen height, $\mathrm{AL}=$ =albumen length .

The phenotypic correlations between linear body measurements at week 1 and at week 6 are presented in Table 4. At week 1 and week 6 , the phenotypic correlations between the body parameters were all positive. Additionally, the relationships were highly significant $(P<0.01)$ except for relationships between body

\section{DISCUSSION}

The heritability of body weight at hatch $(0.82 \pm 0.14)$ is lower than $0.91 \pm 0.11$ reported by Daikwo (2011) and $1.08 \pm 0.17$ reported by Adeogun and Adeoye (2004) but higher than $0.26 \pm 0.16,0.263 \pm 0.098$ and 0.33 reported by El-Full et al. (2001), Vali et al. (2005) and Resende et al. (2005), respectively. The heritability estimate of $0.25 \pm 0.14$ for 4 -week body weight in this study falls within weight and wing length, body weight and breast girth and body weight and shank length at week 1 which were positive but not significant $(P>0.05)$. Also at six weeks of age, relationship between shank length and all other parameters were not significant.

the range of $0.17 \pm 0.60$ computed from sire variance components as reported by Bahie El-Deen (1994) for Japanese quail at 4 weeks of age. Estimates obtained at week $1(0.77 \pm 0.26)$, week $2(0.45 \pm 0.03)$, week 3 $(0.33 \pm 0.15)$ week $5(0.16 \pm 0.04)$ and week $6(0.10 \pm 0.002)$ were lower than values reported by Daikwo (2011) and also at variance with the values reported by El-Full et al. 

quails reared in southern guinea savannah, Nigeria

(2001), Vali et al. (2005) and Resende et al. (2005). The decrease in heritability estimate with age as observed in this study had been reported earlier by Saatci et al. (2002) and Daikwo (2011) for Japanese quails. It would appear that additive genetic effects were more important in affecting body weight of Quails at the early ages than do environmental and non-additive genetic effects. However, this observation is not in consonance with the findings of Resende et al. (2005) who reported that heritability estimates increase with age in Japanese quail and broiler chicken; and Momoh et al. (2013), who reported increasing heritability estimate with age in domestic pigeon. The moderate to high heritability estimates obtained for body weight at ages 1-3 weeks indicates that response to selection for body weight at these ages could be rapid while the low heritability estimates of body weight at weeks 5 and 6 imply that response to selection for body weight at the 5th and 6th week could be slow. An estimate of heritability of body weight gain $\left(h^{2}=0.42 \pm 0.02\right)$ at 2-3 weeks of age is similar to 0.40 reported by Samuel and Chang (1994). The result obtained in this study indicates that, selection for this trait might result in appreciable improvement. Since the growth rate during the 2-3 weeks of age had the highest heritability estimate, it can be used as criterion of selection to improve growth performance of Japanese quail. Except for wing and body lengths, the heritability estimates for shank length and breast girth are high and, therefore, indicate that genetic improvement for shank length and breast girth is possible and fast through mass selection. Genetic improvement for breast girth is particularly important in meat-type poultry because of the high positive correlation between breast girth and meat yield. Wing and body lengths in Japanese quails may be slow in response to genetic improvement due to the low heritability estimates for these traits as shown by this study. Due to the dearth of information in literature on heritability estimates of body measurements in quails, it is not feasible to compare the estimates obtained here for these traits with other previous reports. The heritability estimate obtained for age at first egg $\left(h^{2}=0.48 \pm 0.17\right)$ in this study is similar to 0.42 reported by El-Fiky (1991) but higher than $0.18,0.27$ and $0.31 \pm 0.18$ reported by AbdelMounsef (2005), El-Full (2001) and Daikwo (2011). The corresponding values for weight of first egg agreed with the range of 0.17 to 0.78 reported by Strong et al. (1978) and Farahat (1998). However, El-Full (2001) reported an extremely low heritability estimate of 0.0001 for weight of first egg in Japanese quail while Daikwo (2011) reported 0.04 for the same trait. Heritability estimate of body weight at first egg strongly agreed with the range of 0.25 to 0.59 reported by Shamma (1981) while the value obtained for egg number falls within the range of 0.30 0.41 reported by Tawefeuk (2001) during a 70 days egg production period in Japanese quails. Helal (1995) reported heritability estimates of egg number that ranged from 0.40-0.88 for 12-15 weeks period of egg production in Quail. Heritability value obtained for egg weight is higher than $0.37 \pm 0.09$ documented by Daikwo (2011). The moderate heritability estimates for egg number and body weight at first egg indicate that improvement in these traits would be possible using individual selection method. High estimates recorded for age at first egg, weight of first egg and egg weight suggest that improvement may be rapid using mass selection procedure. Differences in heritability estimates for different populations can be expected since heritability is a property of the population and the size or magnitude of the estimate is highly affected by such factors as selection, environmental deviations and method of estimation. The consistently higher genetic correlations between body weights at different ages than their respective phenotypic correlations have been reported by several others (Bahie-El-Deen, 1994; Farahat, 1998; Daikwo, 2011). The strong and positive genetic relationships as observed between body weights at various ages could mean that the same genes are controlling body weight at different ages. Similarly, high genetic correlations between body weights at early ages with body weights at later ages could indicate that selection for body weight at early ages would improve body weight at later (maturity) ages. However, genetic correlation greater than 1 as obtained between body weights at week 2 and week 5 as well as between body weight at week 4 and week 5 is above parametric range. El-Full et al. (2001) and Daikwo (2011) also recorded values greater than 1 for genetic correlation between body weights in Japanese quails. Problems associated with small data size, sampling error and data imbalance (unequal group sizes) could indicate very high genetic correlations between traits involved, which sometime could be outside parametric range. The phenotypic relationship between body weight and shank length at week $1(0.195)$ and at week $6(0.083)$ fairly agreed with the findings of Adeogun and Adeoye (2004) who reported that, phenotypic correlations of body weight and shank length are positive at all age from 1-6 weeks of age. The all positive and mostly significant phenotypic relationships between linear body parameters and body weight agreed with Oyetade (2011) who reported all positively and 

quails reared in southern guinea savannah, Nigeria

mostly significant $(P<0.05)$ phenotypic relationship between body weight and all linear body measurement at various ages. This all positive and mostly significant phenotypic relationships between linear body parameters

\section{CONCLUSION AND RECOMMENDATIONS}

Genetic parameters of body and egg traits of Japanese quails reared in Southern Guinea Savannah of Nigeria have been provided. The moderate to high heritability estimates obtained for body weight at ages 1-3 weeks indicates that response to selection for body weight at these ages could be rapid while the low heritability estimates of body weight at week 5 and 6 imply that response to selection for body weight at the 5th and 6th week could be slow. The strong and positive genetic relationships as observed between body weights at various ages could mean that the same genes are controlling body weight at different ages. Similarly, high genetic correlations between body weights at early ages

\section{REFERENCES}

Abdel-Mounsef NA 2005. Non-genetic Factors Affecting some Productive Traits in Japanese Quail. MSc. Thesis Fac. of Agric. Al-Azhar Univ. Cairo Egypt. 66pp.

Adeogun 10 and Adeoye AA 2004. Heritability and phenotypic correlations of growth performance traits in Japanese quails. Livestock Research for Rural Development.Vol. 16, Art.\# 103. Retrieved from http://www.irrd.org/irrd16/12/adeo16103.htm

Akpa GN, Kaye J, Adeyinka IA and Kabir M 2008. The relationships between laying age and repeatability of egg quality traits in Japanese quails (Coturnix coturnix japonica), Int. J. of Poult. Sci., 7(6): 555-559.

Bahie El-Deen M. 1994. Selection Indices and Crossing as a Tool for improving Meat and Egg Production in Japanese Quail. Ph. D. Thesis Faculty of Agric. Alexandria Univ. Egypt.138 pp.

Baumgartner J 1993. Japanese quail production, breeding and genetics: proceedings of the 10th international symposium on current problems of Avian Genetics, Nitra, Slovakia. PP 101-103.

Bawa GS 2006. Practical feed formulations and mixing for Quails. A paper presented at the National workshop on quail production for sustainable household protein intake. National Agricultural extension and Research liaison services and body weight indicate that an improvement in one trait could lead to a concomitant improvement in the other if they do demonstrate positive genetic association.

with body weights at later ages could indicate that selection for body weight at early ages would improve body weight at later (maturity) ages.

It is, therefore, recommended that selection for body weight or growth rate in Japanese quails should be carried out at early stages of growth, preferably 2-3 weeks of age. The positive and mostly significant phenotypic relationships between linear body parameters and body weight as observed in this study should be put into consideration in selection exercises for these parameters in Quail populations as phenotypic associations are important in determining the size of selection differentials in selection practices.

(NAERLS). Ahmadu Bello University, Zaria, Sept. 1-13, 2006. PP. 20-32.

Becker WA 1992. Manual of Quantitative Genetics. $5^{\text {th }}$ Edition USA Academic Enterprise Pullman, 189pp.

Chindo HJ and Olowaniyan FO 2006.Processing and utilization of quail products. A paper presented at national workshop on quail production for sustainable household protein intake (NAERLS), Ahmadu Bello University Zaria, September 1113. Pp.69-74.

Dafwang II 2006. Nutrient requirement and feeding regimen in Quail production. A paper presented at national workshop on quail production for sustainable household protein intake (NAERLS), Ahmadu Bello University Zaria September 1113. PP. 12-19.

Daikwo IS 2011. Genetic Studies on Japanese Quail (Coturnix coturnix japonica) in a Tropical Environment. Ph.D. Thesis, College of Animal Science, University of Agriculture Makurdi, Nigeria. 167pp.

El-Fiky FA 1991. Genetic Studies of some Economic Traits in Japanese Quail. Ph.D. Thesis, Fac. Agric. Al-Azhar Univ. Cairo, Egypt. 156PP.

El-Full EA 2001. Genetic analysis of hatched egg weight, body weight at different ages and reproductive performance with their relationships in Japanese quail. Egypt. Poult. Sci. J., 21(11):291-304. 
El-Full EA Ali AA El-Fattah A and Khalifa MA 2001. Inheritance of some growth characteristics of Japanese quail. Egypt poult. Sci. J., 21(3):719739.

Farahat GS 1998. Estimation of some Genetic and Phenotypic Parameters for Growth and Reproductive Traits of Japanese Quail. M.Sc. Thesis, Fac, Agric. Fayoun, Cairo Univ. Egypt.98 pp.

Harvey WR 1990. Mixed Model Least-Squares and Maximum Likelihood Computer Programmer, Ohio State University, Columbus (Mineo).

Helal MA 1995. The Effect of Crossing on the Performance of Japanese Quail. M. Sc. Thesis, Vet. Med. College, Alexandria Univ., Egypt.81 $\mathrm{pp}$.

Kawahara T and Saito K 1976. Genetic parameters of organ and body weight in the Japanese quail. Poult. Sc. J., 55:1247-1252.

Momoh OM Anebi PE and Carew SN 2013. Heritability estimates and phenotypic correlations of body and egg traits of domestic pigeon (Colomba livia domestica) reared On-station in Benue State of Nigeria. Res. Opin. Anim. Vet. Sci., 3(10), 370373.

Modern Farming Methods 2014, http://www.roysfarm.com/quail-farming-in-india

Muthukumar SP and Dev Roy AK 2005. Alternate Poultry Production in India. An overview. Sadana Publishers.

http://www. dairyyearbook.com/poultry

Nasarawa State Ministry of Information 2006. Information Bulletin, 24pp.

NVRI 1996.Manual on Quail Production and Health Management. National Veterinary Research Institute, Vom, Nigeria. $50 \mathrm{pp}$

Oyetade MS 2011. Prediction of Body Weight from Linear Body Measurement in Japanese Quails. B. Agric. Thesis, Dept of Animal Breeding and Genetics. University of Agriculture, Abeokuta, Nigeria. 45pp.
Panda B and Singh RP 1990. Development in Processing of Quail. World's Poult. Sci. J., 46: 219-234.

Resende RO, Martins EN, George PC, Paiva E, Conti ACM, Santos AI, Sakaguti ES and Murakami AE 2005. Variance components for body weight in Japanese quails. Brazil J. Poult. Sci., 7(1):2325.

Saatci M, Dewi I, Aksoy R, Kirmizibayrak T and Ulutas Z 2002. Estimation of genetic parameters for weekly Live weight in one to one sire and dam pedigree recorded Japanese quail. Proceedings of the 7th World Congress on Genetics Applied to Livestock Production, Paris, France. p20.

Samuel EA and Chang KM 1994. Animal model analysis of genetic covariance for growth traits in Japanese quail. Poult. Sci. J. 73:1822-1828.

Shamma TA 1981. Reaktionen Von Watchien Auf verschiedene Stessoren. Dissertation aus deminst fur Tierthaltung und Tirzuchtung der univ. Hohenheim. BRD.

Strong CF Jr., Nestor KE and Bacon W L (1978).Inheritance of egg production, egg weight, body weight and certain plasma constituents in coturnix. Poult. Sci. J., 57:1-9.

Tawefeuk, F. A. 2001. Studies in Quail Breeding using Selection Index for the Improvement of Growth and Egg Production in Japanese Quail. Ph. D. Thesis, Fac. Agric. Tanta Univ. Egypt. 118 pp.

Toelle VD, Havenstein GB, Nestor KE and Harvey WR 1991. Genetic and phenotypic relationships in Japanese Quail. 1. Body weight, carcass and organ measurements. Poult. Sci., 70:1679-1688.

Tuleun CD, Carew SN and Ajiji I 2008. Feeding value of Velvet Bean (Mucunautilis) for laying hens. Livestock Research for Rural Development. Volume 20, Article \#81. Retrieved from http://www.Irrd.org/lrrd20/5/tule20081.htm.

Vali N, Edriss MA and Rahmani HR 2005. Genetic parameters of body and carcass traits in two Quail strains. Int. J. Poult. Sci., 4(5):296-300. 